\title{
Establishing a Learning Community with an Online Orientation
}

Dr. Anne-Marie Balzano

Associate Professor

Education Leadership Program
Dr. Ying-Ying Kuo Instructional Designer

Office of Digital Learning

ITL Conference 2016

George Mason University

$$
\text { 9-16-16 }
$$




\section{First, a bit of program history...}

- Prior to 2014, the Education Leadership program offered no online courses.

$\square$ The EDLE faculty had little to no experience teaching online.

口 DE Grant began in March 2014

As of Fall 2016, our entire MEd program is online, with our fourth cohort starting this semester.

- Waitlist for the Spring 2016 cohort. 


\section{EDLE Program Orientation}

- Five day schedule under Blackboard Organizations, at least one week prior to the start of the first course.

口 Program Overview

- Preparation for Hardware and Software

Keys to Success and Kaltura

- Community Building Activities

- Video Responses and Exit Ticket

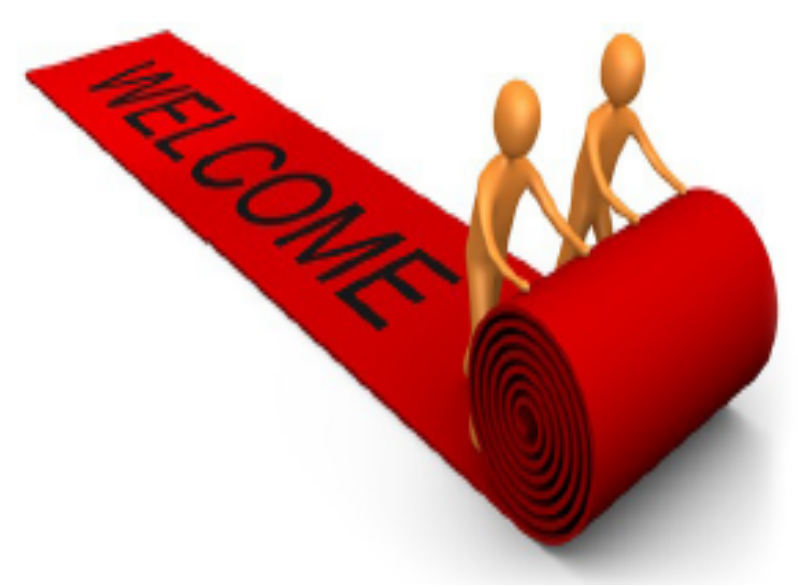




\section{Orientation Design}

$\square$ Practical

口 Program expectations

口 Technology Readiness (Blackboard, Kaltura CaptureSpace)

$\square$ Time Efficient

口 Five days, 30-90 minutes per day

$\square$ Learning Community

口 Students introduce themselves \& interact with each other (Big hit!)

- Communication with advisor/professors (DB/Journals)

口 Supportive activities 


\section{Day 1: Welcome and Program Overview}

- Welcome to Mason and Mason Pride

口 Orientation Schedule

- Program overview, including class list, schedule and links to courses/syllabi

口 Faculty Links

$\square$ Tech Survey

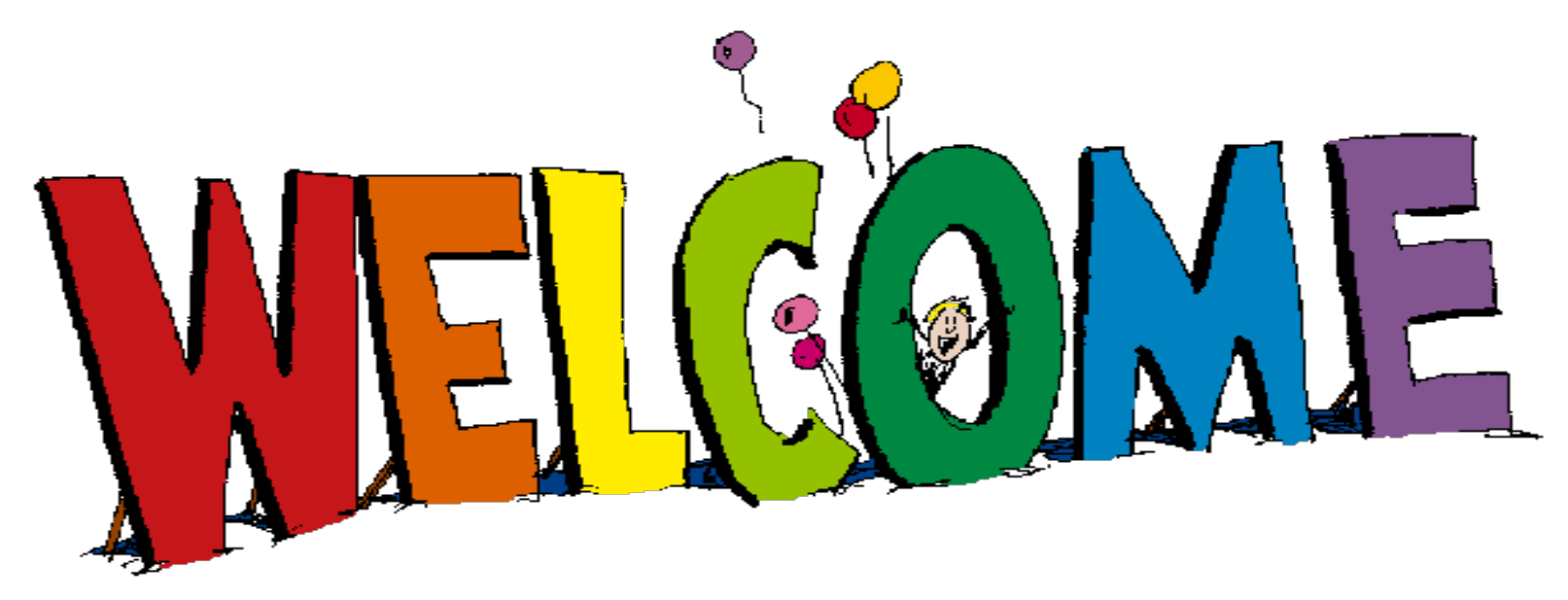




\section{Day 2: Technology Preparation}

$\square$ Hardware and Software Requirements

口 Blackboard Learn Tutorial

$\square$ Journal Activity - Two Truths and a Lie

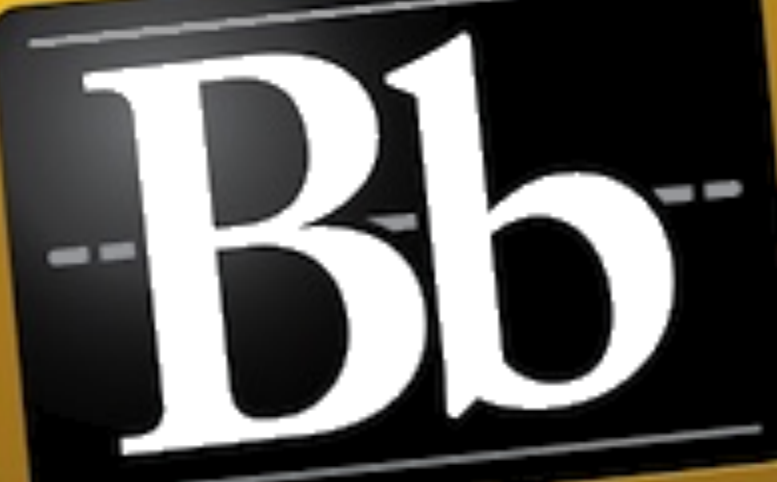




\section{Day 3: Keys to Success and Kaltura}

Key to Success

- Expectations/ Tips for a Successful Online Experience

- Workload/ Group Work Netiquette

口 Leadership Dispositions

- Kaltura CaptureSpace Installation

Discussion Board Post - Qs so far? 口 Response from advisor/professor

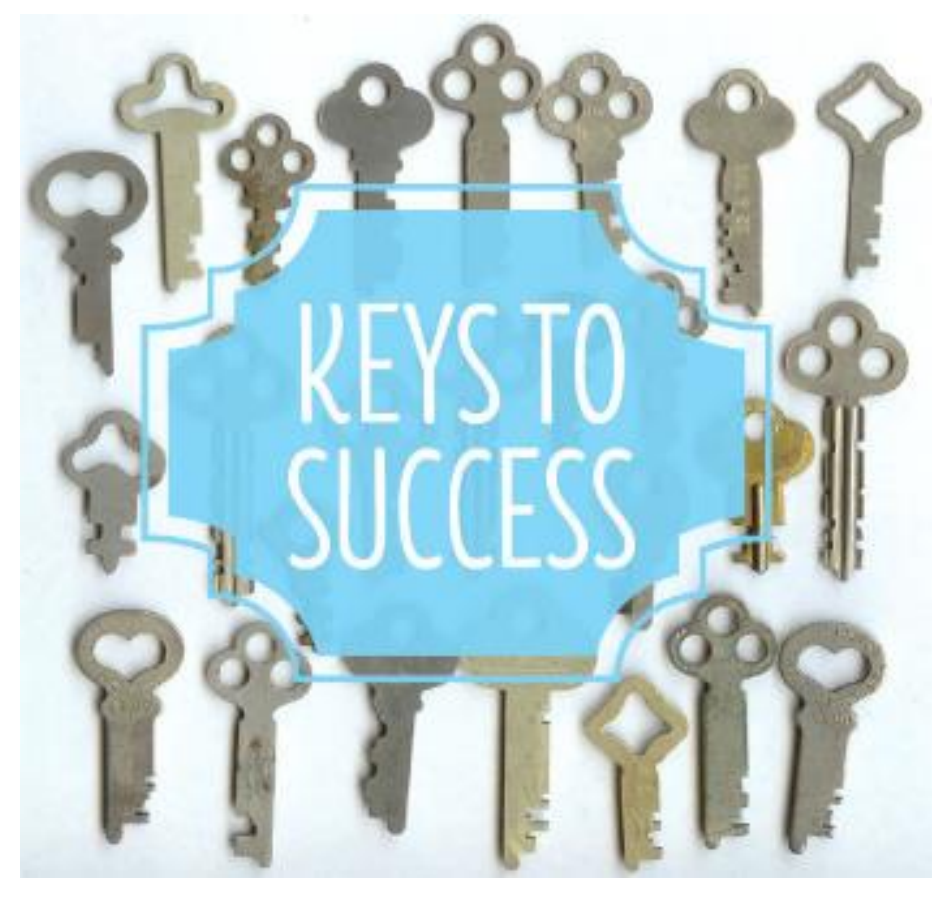




\section{Day 4: Community Building}

- Two Truths and a Lie "Quiz"

口 Student Use Exam Feature

口 Prize given to student with highest score

$\square$ Video Introduction Record/Upload

口 Record 2 minute "Introduce Yourself

- Link video using Kaltura Mashups

口 Post

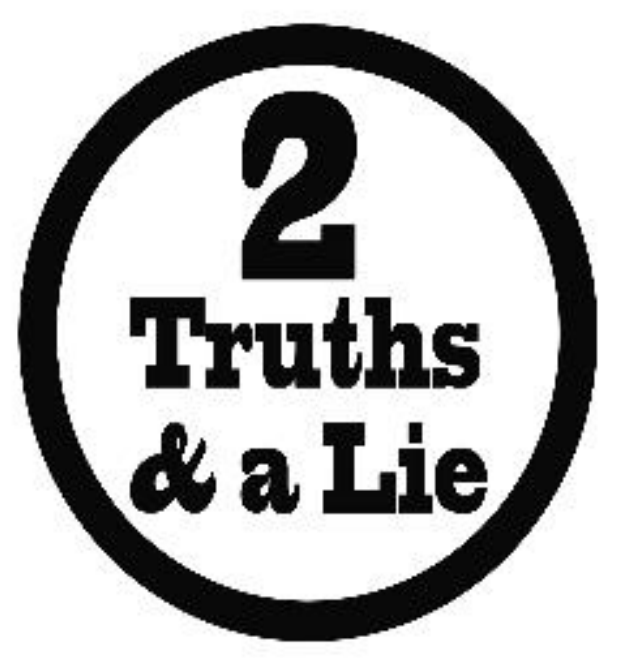




\section{Day 5: Community Building and Exit Ticket (Data Collection)}

Two Truths and a Lie Results

$\square$ Learning community solidifies - Video Responses 口 Student/Professor Interaction

$\square$ Exit Journal Activity Student reflection and feedback - Advisor/prof response

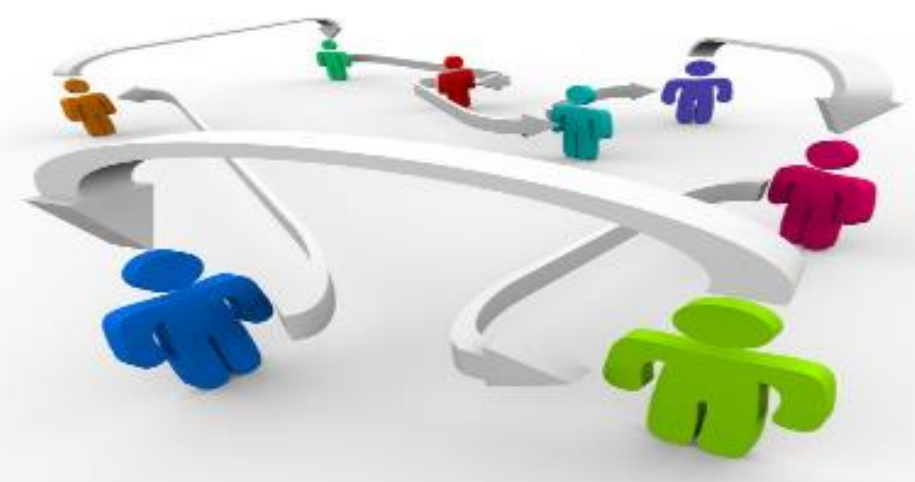




\section{EDLE Program Orientation}

r EDLE Online Orientation Â (2016 Spring Cohort Program)

Home Page Ø

Welcome to the EDLE

Program - Start Here

Orientation Schedule

Day 1: Welcome and Program Overview

Day 2: Preparation for Harcware and Software

Day 3: Keys to Success and Kaltura

Day 4: Community Building Activities

Day 5: Video Responses and Exit Ticket

\section{Bufld Content $\vee \quad$ Assessments $\vee \quad$ Tools $\vee \quad$ Partier Content $\vee$}

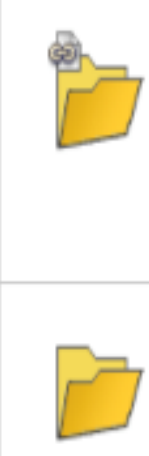

\section{Welcome to the EDLE Program}

Welcome to the EDLE program! We look forward to working with you.

\section{Day 1: Program Overview (Jan. 11)}

In this session, you will learn about the standards that guide the EDLE program, the courses you will take, and meet the EDLE faculty and staff. You will also complete a quick tech survey so we can learn more about your technology competence as you begin the program.

\section{Day 2: Preparation for Hardware and Software (Jan. 12)}

In this session, we will review the hardware and software needed for the on-line program, provide an overview of Blackboard, and prepare for our first community building activity: Two Truths and a Lie! 


\section{Orientation Participants}

\begin{tabular}{|c|c|c|c|c|c|c|}
\hline Cohort & Women & Men & Primary & Secondary & Unknown & Total \\
\hline $\begin{array}{c}\text { Fall } \\
\mathbf{2 0 1 5}\end{array}$ & 18 & 7 & 11 & 11 & 3 & 25 \\
\hline $\begin{array}{c}\text { Spring } \\
\mathbf{2 0 1 6}\end{array}$ & 14 & 6 & 10 & 9 & 1 & 20 \\
$\begin{array}{c}\text { Fall } \\
\mathbf{2 0 1 6}\end{array}$ & 16 & 9 & 8 & 14 & 3 & 25 \\
\hline
\end{tabular}

Note: We have several international students who serve in $\mathrm{K}-12$ sites 


\section{Orientation Participants}

\begin{tabular}{|l|c|c|c|c|}
\hline Cohort & $\begin{array}{c}100 \% \\
\text { Participalion }\end{array}$ & $\begin{array}{c}\text { Partial } \\
\text { Participalion }\end{array}$ & Absence & Total \\
\hline Fall 2015 & $19(76 \%)$ & $6(24 \%)$ & 0 & 25 \\
\hline Spring 2016 & $18(90 \%)$ & $1(5 \%)$ & 1 & 20 \\
\hline Fall 2016 & $20(80 \%)$ & $3(12 \%)$ & 2 & 25 \\
\hline
\end{tabular}




\section{Orientation Participation Results}

\begin{tabular}{|r|c|c|r|}
\hline Cohort & $\begin{array}{c}\text { Total Sessions } \\
\text { Fall 2015 }\end{array}$ & $\begin{array}{c}\text { Introductory Video } \\
\text { Posis }\end{array}$ & Ronge \\
\hline Spring 2016 & 168 & 141 & $4-13$ \\
\hline Fall 2016 & 218 & 149 & $2-18$ \\
\hline
\end{tabular}




\section{Participants' Reflections}

Almost all of the participants' reflections in the Exit Journal:

- Showed positive feelings regarding the orientation

口 Highlighted their appreciation of the design, including

口 Clear instructions

口 Comprehensive navigation

口 Effective community building activities

口 Expressed enjoyment in meeting their fellow cohort members

- Were nervous prior to the orientation but felt more comfortable with the technology afterwards

- Reported they were ready to start the program and look forward to learning 


\section{EDLE Program Orientation}

\section{- Orientation - Student Feedback Samples}

- This is the first online program that I have been a part of, and I think the practice using Blackboard and Kaltura was critical. So, I am glad I had a chance to play with it and learn more about it before assignments and projects will be due.

- It was a great way to gain knowledge on the technical expectations of the course. I like how I had to do activities that taught me where things on blackboard are located.

- One of the hardest things about an online class is feeling disconnected from your classmates and the inability to get to know them on a personal basis but it seems like the introductory video assignment and having to provide multiple, meaningful responses was a great way to give everyone a chance to "introduce" themselves on a personal level. 


\section{EDLE Program Orientation}

$\square$ Orientation - Student Feedback Samples

- This orientation has been one of the best ones I have ever gone through. Too often during an orientation I find myself rolling my eyes at the unrelated activities or steps; that was not the case for this experience. I really appreciate the opportunity to get comfortable with the technology we will be using throughout the program, especially Kaltura. Working with my cohort members and instructor has made me feel more prepared to start next week. I am not as nervous about the programs as I felt like I was before, and I can't wait for the program to start. 


\section{Major Takeaways}

- Students in the first cohort without an orientation said they wish they had one in their exit interviews!

- Students who participate in orientation activities report feeling more connected to their colleagues and advisor, and more comfortable with technology requirements.

- Cohorts who participate in orientation activities build a strong sense of community, as evidenced by their interactions with each other and back channel communications (Facebook page, Google hangouts) 